\title{
DESIGN AND OPTIMIZATION OF FAST DISPERSIBLE FORMULATIONS OF MULTI STRENGTH MELOXICAM TABLETS USING RESPONSE SURFACE METHODOLOGY
}

\author{
HUMA ALI $^{1 *}$, FARYA ZAFAR $^{2}$, SOHAIL KHAN $^{3}$, RIFFAT YASMEEN $^{4}$, RABIA BUSHRA $^{4}$, \\ SABA AIJAZ BALOCH ${ }^{3}$ \\ ${ }^{I}$ Institute of Pharmaceutical Sciences, Jinnah Sindh Medical University, Karachi, Pakistan \\ ${ }^{2}$ Department of Pharmaceutics, Faculty of Pharmacy and Pharmaceutical Sciences, University of Karachi, Karachi, Pakistan \\ ${ }^{3}$ Faculty of Pharmacy, Ziauddin University, Karachi, Pakistan \\ ${ }^{4}$ DCOP, Faculty of Pharmacy, Dow University of Health Sciences, Karachi, Pakistan
}

*corresponding author: humaali80@live.com

Manuscript received: January 2018

\begin{abstract}
The purpose of the current study was to design, develop and optimize fast dispersible tablets (FDT) of meloxicam $7.5 \mathrm{mg}$ and $15 \mathrm{mg}$. For this, CCRD was used with Design Expert ${ }^{\mathbb{B}}$ software. Nine diverse formulations, each of strength $\left(\mathrm{M}_{\mathrm{A}} 1-\mathrm{M}_{\mathrm{A}} 9\right.$; $\mathrm{M}_{\mathrm{B}} 1-\mathrm{M}_{\mathrm{B}}$ 9) (F1 - F9) were designed, with two independent variables, including $\left(\mathrm{X}_{1}\right)$ Croscarmellose (Ac-Di-Sol) $(4-10 \%)$, $\left(\mathrm{X}_{2}\right)$ Microcrystalline cellulose (Avicel PH-102) (50 - 65\%) at five different levels $(1,-1,0, \beta,-\beta)$. Disintegration time $\left(\mathrm{Y}_{1}\right)$ and hardness $\left(\mathrm{Y}_{2}\right)$ were chosen as responses variables. Powder blends of these trial compositions were evaluated for micromeritic parameters and finally six formulations from each batch were qualified for compression stage. The selected formulations were compressed by direct compression procedure. Tablet fill was improved by aspartame, incorporated as a sweetener. Different compendial and non-compendial tests were carried out to determine the quality attributes of FDT of Meloxicam and the results were observed within the adequate values. $M_{A} 6$ and $M_{B} 6$ were selected as the preeminent optimized products on the basis of micromeritic and physicochemical features. $\mathrm{M}_{\mathrm{A}} 6$ and $\mathrm{M}_{\mathrm{B}} 6$ have shown quicker disintegration time i.e. $18 \mathrm{sec} ; 19 \mathrm{sec}$ and optimal percentage release of drug i.e., $99.38 \pm 0.86 \% ; 99.86 \pm 0.91 \%$ and drug recovery (assay) values as $100.76 \pm 0.52 \% ; 100.01 \pm 0.84 \%$ respectively. Correspondingly, predicted and actual values of hardness and disintegration time were found in good correlation. FDTs of Meloxicam were successfully developed using RSM tool, which was found valuable in discovering the consequences of numerous variables on drug processability.
\end{abstract}

\section{Rezumat}

Scopul studiului actual a fost proiectarea, dezvoltarea şi optimizarea comprimatelor rapid dispersabile (FDT) de meloxicam $7,5 \mathrm{mg}$ și $15 \mathrm{mg}$. Pentru aceasta, DRCC a fost utilizat cu software-ul Design Expert ${ }^{\circledR}$. S-au conceput nouă formulări diverse, fiecare cu concentrație (MA1-MA9, MB1-MB9) (F1-F9), cu două variabile independente, incluzând (X1) Croscarmeloză (4 $10 \%$ Celuloză microcristalină (Avicel PH-102) (50 - 65\%) și cinci nivele diferite $(1,-1,0, \beta,-\beta)$. Variabilele de răspuns alese au fost timp de dezintegrare (Y1) și duritate (Y2). Amestecurile de pulberi ale acestor formulări au fost evaluate pentru parametrii micromeritici și în final şase formulări din fiecare lot au fost calificate pentru etapa de comprimare. Formulările selectate au fost comprimate prin procedeul de comprimare directă. Gustul tabletei a fost îmbunătătit prin aspartam, încorporat ca îndulcitor. Au fost efectuate diferite teste compendiale și non compendiale pentru a determina calitatea tabeletelor orodispersabile cu meloxicam, iar rezultatele au fost observate prin prisma valorilor compendiale. MA6 și MB6 au fost selectate ca produse optimizate preeminente pe baza caracteristicilor micromeritice și fizico-chimice. MA6 și MB6 au prezentat un timp de dezintegrare mai rapid, adică $18 \mathrm{sec} ; 19 \mathrm{sec}$ și eliberare optimă (\%) a medicamentului, adică, 99,38 + $0,86 \% ; 99,86 \pm 0,91 \%$ și valori de recuperare $100,76 \pm 0,52 \%$; respectiv $100,01+0,84 \%$. În mod corespunzător, valorile preconizate și obținute ale durității și timpului de dezintegrare au prezentat corelație bună. FDT ale meloxicamului au fost dezvoltate cu succes folosind MRS, care prezintă importanță în descoperirea consecințelor numeroaselor variabile asupra procesabilității substanței.

Keywords: meloxicam, fast dispersible tablets (FDT), hardness, disintegration, CCRD, RSM

\section{Introduction}

Meloxicam is widely used for the management of spondylitis, osteoarthritis and rheumatoid arthritis and also utilized in the treatment of gouty arthritis [1]. In the past few years, pharmaceutical industries have been employing different optimization techniques for the manufacturing of various pharmaceutical dosage forms, particularly statistical design of experiments [2]. Specifically, studies based on experimental design are effectively used for product formulation and/or process optimization. Response surface methodology (RSM) is a useful statistical tool and central composite rotatable design (CCRD) is one of the RSM methods 
FARMACIA, 2019, Vol. 67, 4

that design an effective model by predicting the effects of several formulations on the considered responses [3]. Micromeritic characteristics of powder blends are mainly affected by formulation homogeneity, bulk volume/flow and active surface area. Majority of flow parameters are concurrently dependent on particle size variations, surface morphological characters, electrostatic charges, shape and absorbed moisture levels. Conclusively such variables can affect and change the free flowing patterns of the powders and create momentous impact on the processability and quality of the product $[4,5]$.

Direct compression is one of the manufacturing methods by which tablets are directly compressed with no primary treatment. This method is very economical as compared to other manufacturing procedures [6]. The easy manufacturing procedures of direct compression method are apparent. Data of release profiles of formulations developed by direct compression method demonstrate quick drug release [7].

Nowadays fast dispersible formulations are widely accepted amongst people of all age groups due to the convenience of administration, excellent taste and improved drug bioavailability. Water dispersible formulations are manufactured by various manufacturing procedures, among which, direct compression is the easiest one. Addition of super-disintegrates in dispersible formulations assists in the rapid dispersion of these formulations [8].

FDT may be prepared by using melt granulation, sublimation, phase transition process, freeze drying, spray drying or additionally direct compression. Lacks of physical resistance, poor drug loading and high manufacturing costs of former methods are suggestive for direct compression as the preferred method for FDT [9]. In this work, direct compression (DC) is utilized as cost effective technique owing to its features that no specific equipment is needed and there are fewer processing parameters. Henceforth, the novelty of the presented study is demonstrated in developing and optimizing meloxicam formulations using DC method into fast-dissolving tablets using RSM with central composite rotatable design approach. It is liable to disaggregate by quick penetration of disintegrating fluid, rapid dissolution, and consequently enhanced absorption and bioavailability. Central composite rotatable design (CCRD) is one of the appropriate models that permit most of information with least number of variable enabling systemic predictions of the responses.

In the present study, water dispersible meloxicam ( 7.5 and $15 \mathrm{mg}$ ) tablets were developed using central composite rotatable design (CCRD). Manufacturing of cost-effective formulations with desired quality features have always been a foremost concern during the product development stage. Concentration of binders/fillers and disintegrants produces significant effect on formulation features. Henceforth, in current investigation, two different independent variables (binders and disintegrants) with five levels are used. $2^{\mathrm{k}}$ factorial is used to demonstrate the minimum number of tests needed for the CCRD. Axial fitting of $2^{\mathrm{k}}$ points with a scrupulous distance say â, from the central point is used to institute the quadratic terms. Whereas $\mathrm{k}$ indicates the number of variables used in specific design. Such variables are coded as $0, \pm 1$ and $\pm \beta$ for central, factorial and axial positions respectively [6]. Selection of axial points is based on that they assist rotatability to determine the degree of variation for the predicted model. Furthermore, disintegration time, hardness and friability were chosen as response (dependent) variables.

\section{Materials and Methods}

Meloxicam was gifted from Hilton Pharma (Pvt.) Ltd; Avicel PH-102 and Croscarmellose (Ac-di-sol) from FMC Corporation, USA; and magnesium stearate from Dow Chemical, USA.

Formulations were designed using central composite model from Design Expert software, version 7.0.0, State-Ease, Inc., Minneapolis.

Formulation Design of Fast Dispersible Meloxicam Tablets

A total of eighteen (18) Meloxicam $7.5 \mathrm{mg}$ and $15 \mathrm{mg}$ FDT formulations $\left(\mathrm{M}_{\mathrm{A}} 1-\mathrm{M}_{\mathrm{A}} 9 ; \mathrm{M}_{\mathrm{B}} 1-\mathrm{M}_{\mathrm{B}} 9\right)$ were produced with randomized rotatable central composite design (CCRD) (Design Expert software, version 7.0.0) using two different independent variables i.e., $\left(\mathrm{X}_{1}\right)$ Croscarmellose (Ac-Di-Sol) (4 - 10\%), $\left(\mathrm{X}_{2}\right)$ Microcrystalline cellulose (Avicel PH-102) (50 - 65\%) with five different levels $(1,-1,0, \beta,-\beta)$ (Table I). Responses of hardness $\left(\mathrm{Y}_{1}\right)$ and disintegration time $\left(\mathrm{Y}_{2}\right)$ were selected as dependant or response variable $[4,31]$. Different factors with actual and coded levels of excipients concentrations are summarized in Table I. Correspondingly, formulations compositions of dispersible tablets elucidated through design expert are also presented in Table I.

Estimation of Blending Rate Constant

Mixing efficiency of powder blends were determined by estimating the Blending rate constant. Powder blends were mixed between at 3, 6, 9 and $12 \mathrm{~min}$. Assessment of Micromeritic Properties

Different blends of meloxicam (7.5 mg and $15 \mathrm{mg}$ ) were measured for the angle of repose $(\theta)$, Hausner's ratio (HR) and Carr's index (CI) [4].

Compression of tablets

Tumbling method was used to mix the powder blends ( 6 minutes) of various compositions (Table I). Fixed concentrations of aspartame (flavorant/sweetener $1 \%$ ) i.e., $1.7 \mathrm{mg}$ for $7.5 \mathrm{mg} / 15 \mathrm{mg}$ of FDT and magnesium stearate $(2 \%)$ were incorporated along with the mix of drug and other excipients and passed through 20-mesh sieve size. Direct compression 
method with single punch tablet machine was applied to compress the tablets (Korsch Erweka, Frankfurt, Germany). The levels/concentrations of excipients are presented in Table I.

Physicochemical Assessment of fast dispersible meloxicam formulations

The optimized tablet formulations were selected on the basis of appropriate micromeritic values and assessed by various physical parameters like thickness and diameter test. Vernier calliper was used to calculate the values of these parameters. Hardness was determined by using hardness tester (OSK Fujiwara, Seiki Co. Ltd., Japan), weight variation test was conducted with analytical balance (Mettler Toledo B204-S, Switzerland). Friabilator (GmbH and Co., Bremen, Germany) was used to evaluate the friability of the optimized formulations in the light of the British Pharmacopoeial guidelines [10].

Disintegration Test

Disintegration test was performed using USP < 701> Basket Rack Assembly (Erweka ZT-2 Husenstamn, Germany). Six (6) tablets from each formulation were subjected to disintegration in $900 \mathrm{~mL}$ distilled water for 15 minutes at $15^{\circ} \mathrm{C}-25^{\circ} \mathrm{C} \pm 2{ }^{\circ} \mathrm{C}$ [11]. The desirable time of disintegration for dispersible product is time is 3 minutes [12].

Fitness of Dispersion test

Fitness of dispersion test was carried out by placing two tablets in a $100 \mathrm{~mL}$ flask containing water. Mixture was agitated until a uniform dispersion was obtained. The resultant dispersion was transferred through $710 \mu \mathrm{m}$ mesh sieve. Dispersion must be able to pass through $710 \mu \mathrm{m}$ mesh aperture [12].

Pharmaceutical Assay

Ten tablets were weighed and crushed and an average weight of one tablet was transferred to $100 \mathrm{~mL}$ volumetric flask containing $50 \mathrm{~mL}$ of phosphate buffer $\mathrm{pH}$ 6.8. The contents were shaken and the volume was adjusted up to the mark with same solvent (Solution A). Final solution was prepared by incorporating $1.66 \mathrm{~mL}$ of solution A into $25 \mathrm{~mL}$ flask and volume was adjusted with buffer solution. Absorbance was recorded at $359 \mathrm{~nm}$ using spectrophotometer (UV1800 Shimadzu Corporation, Japan) [12, 13].

\section{Assay method Validation}

In present study, assay method was validated in accordance to the ICH guidelines. Specificity, precision, linearity, accuracy and limit of detection/quantitation (LOD/LOQ) were carried out for meloxicam. Linearity was evaluated from the range of $1-10.0 \mu \mathrm{g} / \mathrm{mL}$. For accuracy, different concentrations $(80 \%, 100 \%$ and $120 \%$ ) were subjected to test conditions, while for sensitivity LOD and LOQ values were calculated. Furthermore, interday and intraday precision and accuracy measurements were also carried out [14].

\section{Dissolution Test}

The percentage (\%) drug release of meloxicam FDT $\left(\mathrm{M}_{\mathrm{A}} 1-\mathrm{M}_{\mathrm{A}} 9 ; \mathrm{M}_{\mathrm{B}} 1-\mathrm{M}_{\mathrm{B}} 9\right)$ was performed by using dissolution apparatus (II) (DA 6D, Veego, India), with $50 \mathrm{rpm}$ at $37^{\circ} \mathrm{C} .900 \mathrm{~mL}$ of a buffer was prepared by dissolving potassium dihydrogen orthophosphate $13.61 \mathrm{~g}$ in $800 \mathrm{~mL}$ of water. $0.5 \mathrm{M}$ sodium hydroxide was used to adjust the $\mathrm{pH}$ to 7.5 , sufficient water was added to produce $1000 \mathrm{~mL}$ solution. The percentage drug release was analysed at $362 \mathrm{~nm}$ [10]. 80\% contents of drug should release in 30 minutes. Standard solution of similar concentration was prepared to compute the meloxicam release.

Stability Studies

Stability studies were carried out using the guidelines of International Committee on Harmonization [15]. Formulations were placed at $40^{\circ} \mathrm{C} \pm 2{ }^{\circ} \mathrm{C}$ and $75 \%$ $\mathrm{RH} \pm 5 \%$ (accelerated conditions) for 6 months in humidity chamber. Disintegration time, assay, dissolution and hardness test were carried out to demonstrate the product stability profile. Pure meloxicam (API) and the powder blends of drug and different excipients incorporated in the formulations of FDT were illustrated by FT IR spectroscopy to identify the compatibility and stability of selected formulations and degradation products under treated conditions.

\section{Results and Discussion}

Over the last couple of years, an inclination has been observed towards the development of such formulations which may be able to enhance patient compliance and satisfaction. In recent days, fast dispersible dosage form has gained substantial attention owing to the fact that it facilitates homogeneous dispersal of drug constituents in water prior to administration. The noteworthy attribute of these formulations is the quick incursion of water in the core of tablet which possibly hastens the mechanism of disintegration and subsequent dissolution [16]. In the present study dispersible forms of tablets were produced choosing meloxicam as model drug. Table I shows the five factors levels applied in the process optimization of meloxicam with coded and actual values for variables (excipients) concentrations using CCRD. Also, detailed descriptions of formulations compositions of FDT are summarized in Table I. Six formulations from each batch were selected for compression on the basis of acceptable excipients concentrations and powder flow characteristics. All selected optimized trial formulations of fast disintegrating meloxicam tablets were then manufactured/compressed by direct compression method. Effect of flow properties on tabletting process has been investigated by a number of authors $[5,6$, $16]$. 
Meloxicam $7.5 \mathrm{mg}$ and $15 \mathrm{mg}$ FDT formulations derived from design expert by using central composite model with actual and coded levels

\begin{tabular}{|c|c|c|c|c|c|c|c|c|c|c|c|}
\hline \multirow{2}{*}{$\begin{array}{l}\text { Formulation } \\
\text { Code }\end{array}$} & \multirow[b]{2}{*}{ Type } & \multicolumn{2}{|c|}{$\mathrm{AL}$} & \multicolumn{2}{|c|}{$\mathrm{CL}$} & \multirow{2}{*}{$\begin{array}{c}\text { Avicel } \\
\text { PH-102 } \\
(\mathrm{mg})\end{array}$} & \multirow{2}{*}{$\begin{array}{c}\text { Crosscarmellose } \\
(\mathrm{mg})\end{array}$} & \multirow{2}{*}{\begin{tabular}{|c|} 
Aspartame \\
$(\mathrm{mg})$
\end{tabular}} & \multirow{2}{*}{$\begin{array}{c}\text { Magnesium } \\
\text { Stearate } \\
(\mathrm{mg})\end{array}$} & \multirow{2}{*}{$\begin{array}{l}\text { API } \\
(\mathrm{mg})\end{array}$} & \multirow{2}{*}{\begin{tabular}{|c|} 
Final \\
Weight
\end{tabular}} \\
\hline & & $\begin{array}{c}\mathrm{X} 1 \\
(\%)\end{array}$ & $\begin{array}{l}\mathrm{X} 2 \\
(\%) \\
\end{array}$ & $\mathrm{X} 1$ & $\mathrm{X} 1$ & & & & & & \\
\hline \multicolumn{12}{|c|}{ Meloxicam $7.5 \mathrm{mg}$ FDT } \\
\hline $\mathrm{M}_{\mathrm{B}} 1$ & Fact & 4 & 50 & -1 & -1 & 170.36 & 13.63 & \multirow[t]{9}{*}{1.7} & 6.81 & \multirow[t]{9}{*}{7.5} & \multirow[t]{9}{*}{200} \\
\hline $\mathrm{M}_{\mathrm{B}} 2$ & Fact & 10 & 50 & 1 & -1 & 153.87 & 30.77 & & 6.15 & & \\
\hline $\mathrm{M}_{\mathrm{B}} 3$ & Fact & 4 & 65 & -1 & 1 & 174.68 & 10.75 & & 5.37 & & \\
\hline $\mathrm{M}_{\mathrm{B}} 4$ & Fact & 10 & 65 & 1 & 1 & 161.06 & 24.78 & & 4.96 & & \\
\hline $\mathrm{M}_{\mathrm{B}} 5$ & Axial & 2.75 & 57.5 & $-1.414(-\beta)$ & 0 & 176.22 & 8.45 & & 6.13 & & \\
\hline $\mathrm{M}_{\mathrm{B}} 6$ & Axial & 11.24 & 57.5 & $1.414(+\beta)$ & 0 & 155.08 & 30.32 & & 5.39 & & \\
\hline $\mathrm{M}_{\mathrm{B}} 7$ & Axial & 7 & 46.89 & 0 & $-1.414(-\beta)$ & 160.08 & 23.90 & & 6.83 & & \\
\hline $\mathrm{M}_{\mathrm{B}} 8$ & Axial & 7 & 68.10 & 0 & $1.414(+\beta)$ & 168.53 & 17.32 & & 4.95 & & \\
\hline $\mathrm{M}_{\mathrm{B}} 9$ & Centre & 7 & 57.5 & 0 & 0 & 164.98 & 20.08 & & 5.74 & & \\
\hline \multicolumn{12}{|c|}{ Meloxicam $15 \mathrm{mg}$ FDT } \\
\hline $\mathrm{M}_{\mathrm{A}} 1$ & Fact & 4 & 50 & -1 & -1 & 163.66 & 13.09 & \multirow[t]{9}{*}{1.7} & 6.55 & \multirow[t]{9}{*}{15} & \multirow[t]{9}{*}{200} \\
\hline $\mathrm{M}_{\mathrm{A}} 2$ & Fact & 10 & 50 & 1 & -1 & 147.82 & 29.56 & & 5.91 & & \\
\hline $\mathrm{M}_{\mathrm{A}} 3$ & Fact & 4 & 65 & -1 & 1 & 167.81 & 10.33 & & 5.16 & & \\
\hline $\mathrm{M}_{\mathrm{A}} 4$ & Fact & 10 & 65 & 1 & 1 & 154.73 & 23.81 & & 4.76 & & \\
\hline $\mathrm{M}_{\mathrm{A}} 5$ & Axial & 2.75 & 57.5 & $-1.414(-\beta)$ & 0 & 169.29 & 8.12 & & 5.89 & & \\
\hline $\mathrm{M}_{\mathrm{A}} 6$ & Axial & 11.24 & 57.5 & $1.414(+\beta)$ & 0 & 148.99 & 29.13 & & 5.18 & & \\
\hline $\mathrm{M}_{\mathrm{A}} 7$ & Axial & 7 & 46.89 & 0 & $-1.414(-\beta)$ & 153.78 & 22.96 & & 6.56 & & \\
\hline $\mathrm{M}_{\mathrm{A}} 8$ & Axial & 7 & 68.10 & 0 & $1.414(+\beta)$ & 161.90 & 16.64 & & 4.75 & & \\
\hline $\mathrm{M}_{\mathrm{A}} 9$ & Centre & 7 & 57.5 & 0 & 0 & 158.49 & 19.29 & & 5.51 & & \\
\hline
\end{tabular}

$\mathrm{AL}=$ Actual level; $\mathrm{CL}=$ Coded Level; X1 = Croscarmellose; X2 = Avicel PH 102

Experimental contemplation of Carr's index, Hausner's ratio and angle of repose as declared in the United States Pharmacopeia were pursued [11]. Meloxicam powder blends $\left(\mathrm{M}_{\mathrm{A}} 1-\mathrm{M}_{\mathrm{A}} 9 ; \mathrm{M}_{\mathrm{B}} 1-\mathrm{M}_{\mathrm{B}} 9\right)$ were assessed by a number of flow parameters like angle of repose, Hausner's ratio and Carr's index. Results of current study revealed the comparatively smaller values of Carr's index while angle of repose and Hausner's ratio have demonstrated the acceptable flow and compressibility features except $\mathrm{M}_{\mathrm{A}} 1, \mathrm{M}_{\mathrm{A}} 3, \mathrm{M}_{\mathrm{A}} 5$ and $M_{B} 1, M_{B} 3, M_{B} 5$ (Table II). These formulations were also excluded due the lower concentration of disintegrant, as rapid disintegration is prerequisite for FDT. Evaluation of powder blend properties provides valuable information to the researcher that seems to be necessary for obtaining the most appropriate blend of the excipients and the API. Carr's index (CI) demonstrates the strength of powder bridges and successive stability, while Hausner's ratio (HR) depicts the inter-particulate friction. Lower CI and HR values of a material designated as superior/better flow behaviour than elevated ones. The angle of repose is a customary approach to describe flow of pharmaceutical powder $[17,18]$. Higher values (Poor flow; $\theta$ between $46-55^{\circ}$ ) of angle of repose may require agitation and vibration to flow the powder, while passable range of powder may hang up during flow. On the basis of these parameters, powder blends of meloxicam were selected, which showed satisfactory flow behaviours for compression (Table II). Alterations in micromeritic properties were probably due to the variable concentrations of excipients including avicel $\mathrm{PH}$ 102 and crosscarmellose. Avicel PH 102 has direct relation with compressibility index and Hausner's ratio. Another study also reported the consequences of granular form and size of particle for avicel PH102 in order to enhance the flow properties [19]. The overall average values of three factors i.e. angle of repose, Carr's index and Hausner's ratio were in order of $30.7 \pm 0.32^{\circ}$ to $36.3 \pm 0.09^{\circ}, 13.7 \pm$ $0.26 \%$ to $25.7 \pm 0.19 \%$ and $1.12 \pm 0.06$ to $1.22 \pm$ 0.05 as mentioned in Table II. Powders with such characteristics are proficient to fabricate tablets with acceptable weight variation. The flow pattern deviation of powder mixture could be affected by the properties of manufacturing equipment or powder particles characters [20]. Blending rate constant was determined to observe the impact of mixing time on formulation homogeneity and it was observed to be 6 minutes. Triplicates of blends have shown least values of relative standard deviation (\% RSD) at 6 minutes.

In the current study, numerous pharmacopeial and non-pharmacopeial tests results were observed to be in satisfactory limits. Diameter, thickness, mean weight, hardness and friability of $\mathrm{M}_{\mathrm{A}} 2-\mathrm{M}_{\mathrm{A}} 9$ and $\mathrm{M}_{\mathrm{B}} 2-\mathrm{M}_{\mathrm{B}}$ 9 were ranged of $9.89 \pm 0.89 \mathrm{~mm}-9.94 \pm$ $0.49 \mathrm{~mm}, 2.89 \pm 0.27 \mathrm{~mm}-2.95 \pm 0.23 \mathrm{~mm}, 201 \pm$ $3.54 \mathrm{mg}-209 \pm 1.87 \mathrm{mg}, 3.87 \pm 0.42 \mathrm{~kg}-5.12 \pm$ 0.67 and $0.63 \%-0.85 \%$ respectively (Table III). Friability test primarily used to estimate the strength of tablet and the limit for dispersible formulation lies 
FARMACIA, 2019, Vol. 67, 4

in the range of $0.95-1.5 \%$. Hardness, another attribute of tablets, mainly influences the disintegration

potential of formulations $[21,22]$.

Table II

Evaluation of powder blends of different formulations of meloxicam $7.5 \mathrm{mg}$ and $15 \mathrm{mg}(\mathrm{N}=3)$

\begin{tabular}{|c|c|c|c|}
\hline Formulations & Angle of Repose $(\boldsymbol{\theta})$ & Hausner's Ratio & Carr's Index (\%) \\
\hline $\mathbf{M}_{\mathbf{A}} \mathbf{2}$ & $31.4 \pm 0.15$ & $1.16 \pm 0.15$ & $16.7 \pm 0.21$ \\
\hline $\mathbf{M}_{\mathbf{A}} \mathbf{4}$ & $35.7 \pm 0.21$ & $1.19 \pm 0.22$ & $16.6 \pm 0.06$ \\
\hline $\mathbf{M}_{\mathbf{A}} \mathbf{6}$ & $36.3 \pm 0.09$ & $1.20 \pm 0.18$ & $21.2 \pm 0.18$ \\
\hline $\mathbf{M}_{\mathbf{A}} \mathbf{7}$ & $31.2 \pm 0.17$ & $1.21 \pm 0.08$ & $17.9 \pm 0.14$ \\
\hline $\mathbf{M}_{\mathbf{A}} \mathbf{8}$ & $35.5 \pm 0.22$ & $1.22 \pm 0.05$ & $23.1 \pm 0.23$ \\
\hline $\mathbf{M}_{\mathbf{A}} \mathbf{9}$ & $30.7 \pm 0.32$ & $1.20 \pm 0.17$ & $19.0 \pm 0.25$ \\
\hline $\mathbf{M}_{\mathbf{B}} \mathbf{2}$ & $32.5 \pm 0.18$ & $1.18 \pm 0.14$ & $25.7 \pm 0.19$ \\
\hline $\mathbf{M}_{\mathbf{B}} \mathbf{4}$ & $34.5 \pm 0.25$ & $1.12 \pm 0.09$ & $23.4 \pm 0.16$ \\
\hline $\mathbf{M}_{\mathbf{B}} \mathbf{6}$ & $31.7 \pm 0.27$ & $1.21 \pm 0.04$ & $22.8 \pm 0.34$ \\
\hline $\mathbf{M}_{\mathbf{B}} \mathbf{7}$ & $30.3 \pm 0.21$ & $1.12 \pm 0.06$ & $16.8 \pm 0.18$ \\
\hline $\mathbf{M}_{\mathbf{B}} \mathbf{8}$ & $30.8 \pm 0.11$ & $1.23 \pm 0.16$ & $13.7 \pm 0.26$ \\
\hline $\mathbf{M}_{\mathbf{B}} \mathbf{9}$ & $34.6 \pm 0.32$ & $1.12 \pm 0.14$ & $18.3 \pm 0.29$ \\
\hline
\end{tabular}

Table III

Physical evaluation of trial formulations of meloxicam $7.5 \mathrm{mg}$ and $15 \mathrm{mg}$

\begin{tabular}{|c|c|c|c|c|c|c|c|c|c|}
\hline $\begin{array}{c}\text { Formulations } \\
\text { Code }\end{array}$ & $\begin{array}{c}\text { Diameter } \\
(\mathbf{m m}) \\
(\mathbf{N}=\mathbf{2 0})\end{array}$ & $\begin{array}{c}\text { Hardness } \\
(\mathbf{k g}) \\
(\mathbf{N}=\mathbf{2 0}) \\
\end{array}$ & $\begin{array}{c}\text { Weight } \\
\text { (mg) } \\
(\mathrm{N}=\mathbf{2 0})\end{array}$ & $\begin{array}{c}\text { Thickness } \\
\text { (mm) } \\
(\mathbf{N}=\mathbf{2 0})\end{array}$ & \begin{tabular}{|c|}
$\begin{array}{c}\text { Disintegration } \\
\text { (Seconds) } \\
(\mathbf{N}=6)\end{array}$ \\
\end{tabular} & $\begin{array}{c}\begin{array}{c}\text { Friability } \\
(\%) \\
(\mathrm{N}=10)\end{array} \\
\end{array}$ & $\begin{array}{c}\text { Drug Release } \\
(\%) \\
(\mathrm{N}=6) \\
\end{array}$ & $\begin{array}{c}\text { Dispersion } \\
\text { test }\end{array}$ & $\begin{array}{c}\text { Assay } \\
(\%) \\
(\mathrm{N}=\mathbf{2 0})\end{array}$ \\
\hline $\mathbf{M}_{\mathrm{A}} 2$ & $9.89 \pm 0.89$ & $3.87 \pm 0.42$ & $206 \pm 2.56$ & $2.91 \pm 0.58$ & $8 \mathrm{sec}$ & 0.68 & $97.36 \pm 0.67$ & \multirow[t]{12}{*}{ Passes } & $99.77 \pm 0.48$ \\
\hline$M_{A} 4$ & $9.91 \pm 0.26$ & $4.69 \pm 0.26$ & $205 \pm 3.08$ & $2.94 \pm 0.19$ & $7 \mathrm{sec}$ & 0.85 & $98.32 \pm 0.43$ & & $99.51 \pm 0.33$ \\
\hline$M_{A} 6$ & $9.92 \pm 0.57$ & $5.12 \pm 0.67$ & $201 \pm 3.54$ & $2.95 \pm 0.23$ & $7 \mathrm{sec}$ & 0.65 & $99.38 \pm 0.86$ & & $100.76 \pm 0.52$ \\
\hline $\mathbf{M}_{\mathrm{A}} 7$ & $9.90 \pm 0.35$ & $4.53 \pm 0.48$ & $208 \pm 5.01$ & $2.89 \pm 0.27$ & $5 \mathrm{sec}$ & 0.68 & $97.02 \pm 0.28$ & & $99.81 \pm 0.67$ \\
\hline $\mathbf{M}_{\mathrm{A}} \mathbf{8}$ & $9.92 \pm 0.62$ & $4.25 \pm 0.58$ & $204 \pm 1.74$ & $2.93 \pm 0.69$ & $5 \mathrm{sec}$ & 0.76 & $96.34 \pm 0.36$ & & $99.46 \pm 0.48$ \\
\hline$M_{A} 9$ & $9.94 \pm 0.49$ & $4.32 \pm 0.82$ & $208 \pm 2.09$ & $2.95 \pm 0.48$ & $10 \mathrm{sec}$ & 0.75 & $97.39 \pm 0.25$ & & $99.51 \pm 0.39$ \\
\hline $\mathbf{M}_{\mathrm{B}} 2$ & $9.91 \pm 0.64$ & $5.03 \pm 0.68$ & $209 \pm 1.87$ & $2.93 \pm 0.75$ & $9 \mathrm{sec}$ & 0.63 & $99.83 \pm 0.89$ & & $100.26 \pm 0.75$ \\
\hline$M_{B} 4$ & $9.92 \pm 0.79$ & $4.37 \pm 0.56$ & $204 \pm 3.25$ & $2.94 \pm 0.92$ & $8 \mathrm{sec}$ & 0.78 & $98.39 \pm 0.32$ & & $99.45 \pm 0.59$ \\
\hline$M_{B} 6$ & $9.90 \pm 0.75$ & $4.18 \pm 0.78$ & $202 \pm 2.36$ & $2.90 \pm 0.64$ & $7 \mathrm{sec}$ & 0.67 & $99.86 \pm 0.91$ & & $100.01 \pm 0.84$ \\
\hline $\mathbf{M}_{\mathrm{B}} 7$ & $9.91 \pm 0.93$ & $4.92 \pm 0.69$ & $205 \pm 2.87$ & $2.92 \pm 0.52$ & $8 \mathrm{sec}$ & 0.69 & $97.54 \pm 0.51$ & & $99.12 \pm 0.93$ \\
\hline $\mathbf{M}_{\mathrm{B}} 8$ & $9.93 \pm 0.76$ & $4.79 \pm 0.46$ & $207 \pm 1.89$ & $2.93 \pm 0.86$ & $4 \mathrm{sec}$ & 0.84 & $98.45 \pm 0.54$ & & $98.78 \pm 0.83$ \\
\hline $\mathbf{M}_{\mathrm{B}} 9$ & $9.91 \pm 0.85$ & $4.53 \pm 0.59$ & $203 \pm 3.46$ & $2.91 \pm 0.55$ & $5 \mathrm{sec}$ & 0.79 & $97.56 \pm 0.67$ & & $99.24 \pm 0.15$ \\
\hline $\begin{array}{c}\text { Reference } \\
\left(\text { Mel }_{7.5}\right)\end{array}$ & $10.22 \pm 0.46$ & $6.52 \pm 0.66$ & $193 \pm 0.55$ & $2.72 \pm 0.96$ & $45 \mathrm{sec}$ & 0.51 & $98.34 \pm 0.21$ & NA & $97.64 \pm 0.88$ \\
\hline $\begin{array}{c}\text { Reference } \\
\left(M^{\prime} l_{15}\right)\end{array}$ & $9.06 \pm 0.12$ & $7.54 \pm 0.57$ & $253 \pm 1.27$ & $3.21 \pm 0.54$ & $42 \mathrm{sec}$ & 0.66 & $97.52 \pm 0.58$ & NA & $98.54 \pm 0.88$ \\
\hline
\end{tabular}

NA $=$ not applicable

The results of the disintegration test were found in adequate limit of 18 - 42 seconds. These findings of tablet disintegration and drug release characters of all trial FDT formulations $\left(\mathrm{M}_{\mathrm{A}} 1-\mathrm{M}_{\mathrm{A}} 9 ; \mathrm{M}_{\mathrm{B}} 1-\mathrm{M}_{\mathrm{B}} 9\right)$ described the significant association between the quantity of binder and disintegrants and drug disaggregation and dissolution mechanisms. Furthermore, fineness of dispersion test was also carried out and all formulations have shown satisfactory test results (Table III). Release of drug in biological fluid is pre-requisite for optimal absorption and subsequent bioavailability. In this study, the percentage release of FDT of meloxicam $\left(\mathrm{M}_{\mathrm{A}} 1-\mathrm{M}_{\mathrm{A}} 9 ; \mathrm{M}_{\mathrm{B}} 1-\mathrm{M}_{\mathrm{B}} 9\right)$ was evaluated by using phosphate buffer $\mathrm{pH} 7.5$ according to BP, 2013 method [10]. Results demonstrated the satisfactory release within allowable time i.e., $30 \mathrm{~min}$ (Table III). Dissolution studies indicated adequate release of fast dispersible formulations and values of dissolved contents were found in the range of
$96.34 \pm 0.36 \%$ to $99.83 \pm 0.89 \%$ (Table III). Mostly FDT mainly composed of diverse excipients ratios that initiate complex dissolution procedure after solvent diffusion in to the matrix of the tablet [23, 24]. Assays measurement of $M_{A} 1-M_{A} 9 ; M_{B} 1-M_{B} 9$ were found to be in limit of $98.78 \pm 0.83 \%-100.76 \pm$ $0.52 \%$ as summarized in Table III. Moreover, various physicochemical attributes of marketed brands $\left(\mathrm{Mel}_{7.5}\right.$ and $\mathrm{Mel}_{15}$ ) were also determined and presented in Table III. $\mathrm{M}_{\mathrm{A}} 6$ and $\mathrm{M}_{\mathrm{B}} 6$ were chosen as the exceptional optimized products on the basis of their excellent pharmaceutical attributes. $\mathrm{M}_{\mathrm{A}} 6$ and $\mathrm{M}_{\mathrm{B}} 6$ have tablet mean weight of $201 \pm 3.54 \mathrm{mg} ; 202 \pm 2.36$ with faster disintegration time i.e. $18 \mathrm{sec} ; 19 \mathrm{sec}$ and optimal $\%$ release of drug i.e., $99.38 \pm 0.86 \%$; $99.86 \pm 0.91 \%$ and drug recovery (assay) values as $100.76 \pm 0.52 \%$; $100.01 \pm 0.84 \%$ respectively.

Table IV presents our data regarding the validation parameters for meloxicam $15 \mathrm{mg}$ tablets. 
Table IV

Assay method validation for meloxicam tablets

\begin{tabular}{|c|c|c|c|}
\hline \multicolumn{4}{|c|}{ Accuracy and Percentage Recovery Studies } \\
\hline Concentration Level & Amount incorporated $(\mu \mathrm{g} / \mathrm{mL})$ & calculated concentration $(\mu \mathrm{g} / \mathrm{mL})$ & Percentage recovery $(\%)$ \\
\hline $80 \%$ & 8 & 8.12 & 101.5 \\
\hline $100 \%$ & 10 & 10.07 & 100.7 \\
\hline $120 \%$ & 12 & 11.98 & 99.83 \\
\hline \multicolumn{4}{|c|}{ Specificity studies with respect to Effect of Common Excipients on recovery of Meloxicam $(15 \mathrm{mg})$} \\
\hline \multicolumn{2}{|c|}{ Magnesium stearate } & 14.87 & 99.13 \\
\hline \multicolumn{2}{|c|}{ Microcrystalline Cellulose } & 15.24 & 101.6 \\
\hline \multicolumn{2}{|c|}{ Croscarmellose } & 15.09 & 100.6 \\
\hline \multicolumn{4}{|c|}{ Linearity, Range and Regression Statistics } \\
\hline Slope & 0.0816 & $\mathrm{LOD}(\mu \mathrm{g} / \mathrm{mL})$ & 0.3127 \\
\hline y-Intercept & 0.0912 & LOQ $(\mu \mathrm{g} / \mathrm{mL})$ & 0.9476 \\
\hline Regression equation & $\mathrm{Y}=0.087 \mathrm{X}$ & $\mathrm{R}^{2}$ & 0.992 \\
\hline Range & \multicolumn{3}{|c|}{$1-10(\mu \mathrm{g} / \mathrm{mL})$} \\
\hline \multicolumn{4}{|c|}{ Precision measurement } \\
\hline Interday Precision & \multicolumn{3}{|c|}{$\% \mathrm{CV}$ was found to be $<2$ at selected conc. level } \\
\hline Intraday Precision & \multicolumn{3}{|c|}{$\% \mathrm{CV}$ was found to be $<2$ at selected conc. level } \\
\hline
\end{tabular}

Application of Response Surface Methodology (RSM) This study was based on the RSM application to monitor the impact of contingent variables (X1 - X2) on selected responses (Y1 - Y2). Quadratic models were analysed to evaluate the associations of excipients factors on hardness and disintegration time (DT). Statistical presentations (ANOVA) of response variables using quadratic model terms are shown in Table $\mathrm{V}$ for $15 \mathrm{mg}$ and $7.5 \mathrm{mg}$ meloxicam formulations. The adjusted values of regression $\left(\mathrm{r}^{2}\right)$ disintegration and hardness were $0.906,0.934$ for $7.5 \mathrm{mg}$ meloxicam and 0.864 and 0.896 for $15 \mathrm{mg}$ formulations respectively, reflecting the suitability of the models. When considering model summary statistics and selection of appropriate model, main focus is mainly on the model maximizing the "Adjusted" R-Square and the "Predicted" R-Square. Values of "Prob $>$ F" less than 0.0500 indicate that model terms are significant (Table V). Values greater than 0.1000 indicate the model terms are not significant. Adequate Precision measures the signal to noise ratio. A ratio greater than 4 is desirable. The ratio of 5.303, 8.029 for DT model for $15 \mathrm{mg}$ and $7.5 \mathrm{mg}$ respectively and 9.690 and 14.612 for hardness model for similar trial products indicate the adequate signal for selected design in this investigation (Table V).

Anova for response surface quadratic models for meloxicam 7.5 and $15 \mathrm{mg}$ formulations

\begin{tabular}{|c|c|c|c|c|c|}
\hline \multicolumn{6}{|c|}{ MELOXICAM $15 \mathrm{mg}$} \\
\hline Factors & Sum of Squares & df & Mean Square & F-value & p-value \\
\hline \multicolumn{6}{|c|}{ Disintegration time } \\
\hline Model & 156.8704 & 5 & 31.37408 & 3.812912 & 0.1499 \\
\hline A-X1-croscarmellose & 118.0256 & 1 & 118.0256 & 14.34373 & 0.0323 \\
\hline B- X2- Avicel 102 & 2.914214 & 1 & 2.914214 & 0.354166 & 0.5937 \\
\hline $\mathrm{AB}$ & 4 & 1 & 4 & 0.486122 & 0.5358 \\
\hline $\mathrm{A}^{\wedge} 2$ & 12.375 & 1 & 12.375 & 1.503941 & 0.3075 \\
\hline $\mathrm{B}^{\wedge} 2$ & 1.375 & 1 & 1.375 & 0.167105 & 0.7101 \\
\hline Residual & 24.68514 & 3 & 8.228379 & & \\
\hline Cor Total & 181.5556 & 8 & & & \\
\hline Std. Dev. & \multicolumn{5}{|c|}{0.868515} \\
\hline Mean & \multicolumn{5}{|c|}{10.22222} \\
\hline C.V. \% & \multicolumn{5}{|c|}{2.806156} \\
\hline Adequate Precision & \multicolumn{5}{|c|}{5.30261} \\
\hline \multicolumn{6}{|c|}{ Hardness } \\
\hline Model & 2.367241 & 2 & 1.18362 & 35.71426 & 0.0005 \\
\hline A-X1-croscarmellose & 0.008404 & 1 & 0.008404 & 0.253576 & 0.6325 \\
\hline B- X2- Avicel 102 & 2.358837 & 1 & 2.358837 & 71.17494 & 0.0002 \\
\hline Residual & 0.198848 & 6 & 0.033141 & & \\
\hline Cor Total & 2.566089 & 8 & & & \\
\hline Std. Dev. & \multicolumn{5}{|c|}{0.182048} \\
\hline Mean & \multicolumn{5}{|c|}{4.088889} \\
\hline C.V. \% & \multicolumn{5}{|c|}{4.452255} \\
\hline Adeq Precision & \multicolumn{5}{|c|}{14.612} \\
\hline
\end{tabular}


FARMACIA, 2019, Vol. 67, 4

\begin{tabular}{|c|c|c|c|c|c|}
\hline \multicolumn{6}{|c|}{ "MELOXICAM $7.5 \mathrm{mg}$} \\
\hline Factors & Sum of Squares & df & Mean Square & F-value & p-value \\
\hline \multicolumn{6}{|c|}{ Disintegration time } \\
\hline Model & 2.25064 & 2 & 1.125321 & 11.05497 & 0.0097 \\
\hline A-X1-croscarmellose & 0.06298 & 1 & 0.062982 & 0.618724 & 0.4615 \\
\hline B- X2- Avicel 102 & 2.18765 & 1 & 2.187659 & 21.49122 & 0.0036 \\
\hline Residual & 0.61075 & 6 & 0.101793 & & \\
\hline Cor Total & 2.8614 & 8 & & & \\
\hline Std. Dev. & \multicolumn{5}{|c|}{0.13905} \\
\hline Mean & \multicolumn{5}{|c|}{4.03333} \\
\hline C.V.\% & \multicolumn{5}{|c|}{3.4475} \\
\hline Adequate Precision & \multicolumn{5}{|c|}{8.02955} \\
\hline \multicolumn{6}{|c|}{ Hardness } \\
\hline Model & 25.4779 & 2 & 12.73896 & 16.11065 & 0.0039 \\
\hline A-X1-croscarmellose & 24.74937 & 1 & 24.74937 & 31.29992 & 0.0014 \\
\hline B- X2- Avicel 102 & 0.728553 & 1 & 0.728553 & 0.921384 & 0.3742 \\
\hline Residual & 4.7443 & 6 & 0.790717 & & \\
\hline Cor Total & 30.22222 & 8 & & & \\
\hline Std. Dev. & \multicolumn{5}{|c|}{0.889223} \\
\hline Mean & \multicolumn{5}{|c|}{8.555556} \\
\hline C.V. \% & \multicolumn{5}{|c|}{10.39351} \\
\hline Adequate Precision & \multicolumn{5}{|c|}{9.690189} \\
\hline
\end{tabular}

Such model can be used to navigate the design space. Selecting the highest order polynomial where the additional terms are significant and the model is not aliased. A number of authors previously used central composite design for optimization of different products using numerous sets of variables and responses [2528].

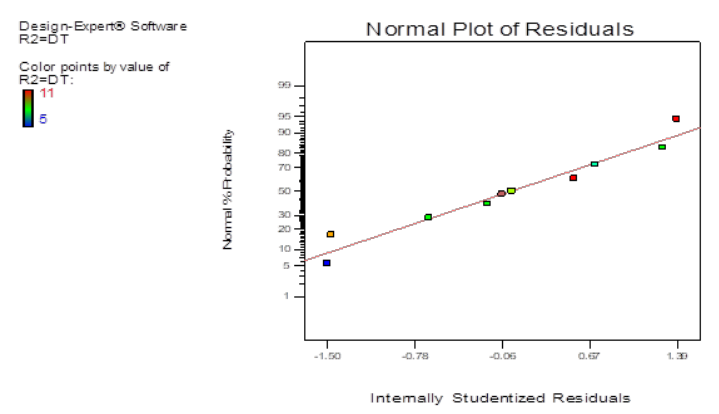

(A)

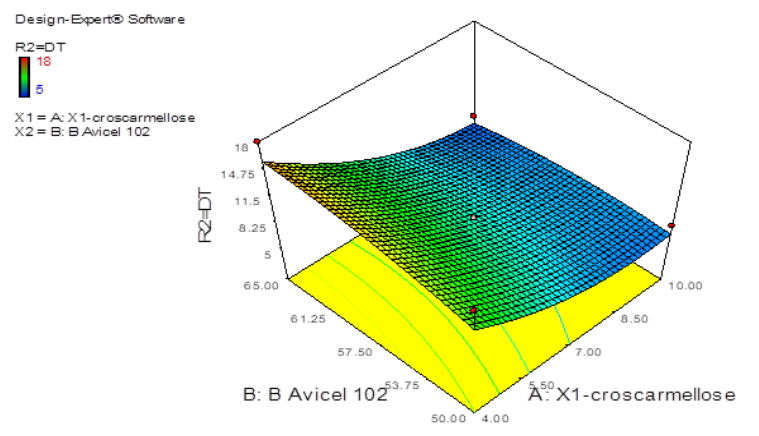

(C)
Effect of excipients/adjuvants on disintegration time In the present study, the disintegration time $\left(\mathrm{M}_{\mathrm{A}} 1-\mathrm{M}_{\mathrm{A}} 9\right.$; $M_{B} 1-M_{B}$ ) was found in adequate limit. Results are summarized in Table III. Normal plots of residuals (Figure 1A), contour plots (Figure 1B), three dimensional plots (3D) of RSM (Figure 1C) and Standard Error plots of disintegration (Figure 1D) for $7.5 \mathrm{mg}$ meloxicam tablets are constructed and presented in Figure 1.
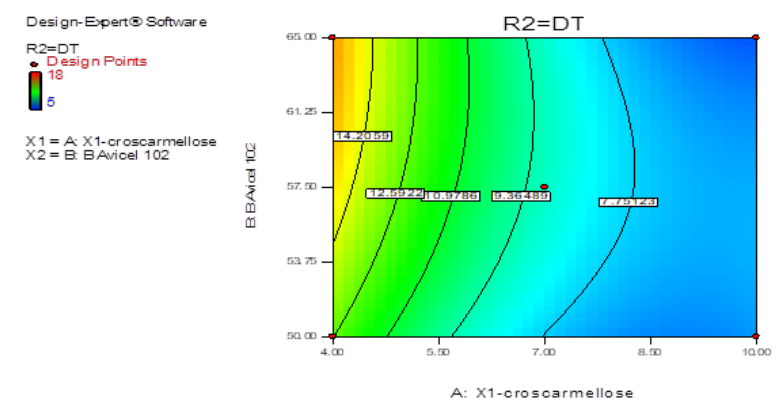

(B)

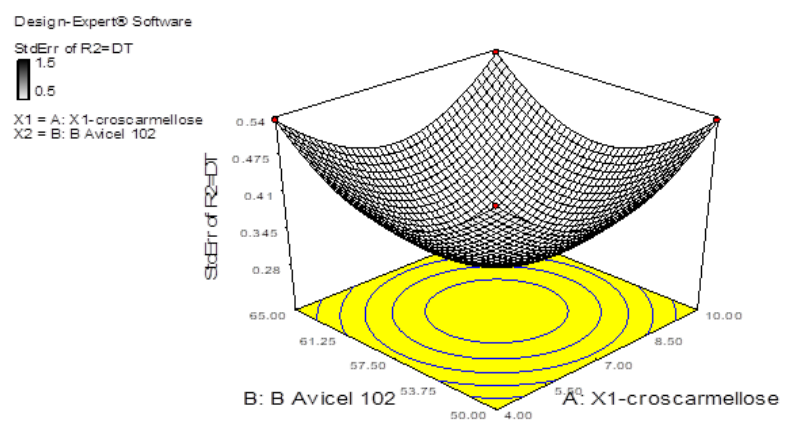

(D)

Figure 1.

Graphical RSM effects of excipients on Disintegration time (DT) of meloxicam $7.5 \mathrm{mg}$ tablets 
Similar plots for $15 \mathrm{mg}$ meloxicam were presented in the Figure 2. These figures indicated the appropriateness of selected concentrations of Avicel PH 102 (binder; $\mathrm{X} 1: 50-65 \%$ ) and croscarmellose (superdisintegrant; $\mathrm{X} 2: 4-10 \%)$ as all directly compressed formulations $\left(\mathrm{M}_{\mathrm{A}} 2-\mathrm{M}_{\mathrm{A}} 9 ; \mathrm{M}_{\mathrm{B}} 2-\mathrm{M}_{\mathrm{B}} 9\right)$ demonstrated the quick disintegration time (18 - $42 \mathrm{~s})$. Diagnostic plots like normal probability plot of the studentized residuals are important to check for normality of residuals, while studentized residuals versus predicted values are used to check the constant error. Externally studentized
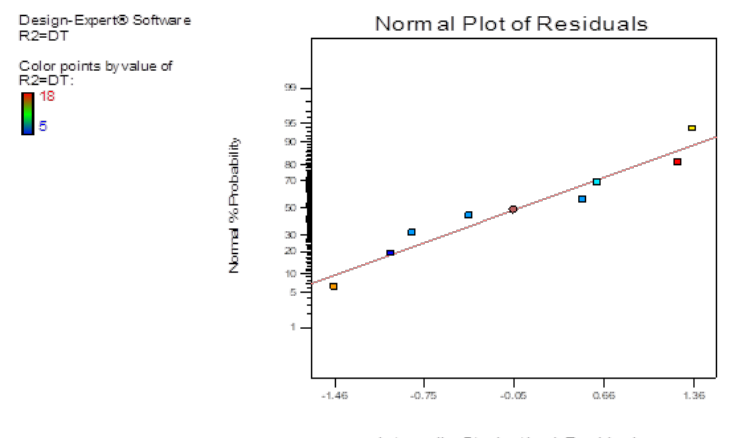

(A)

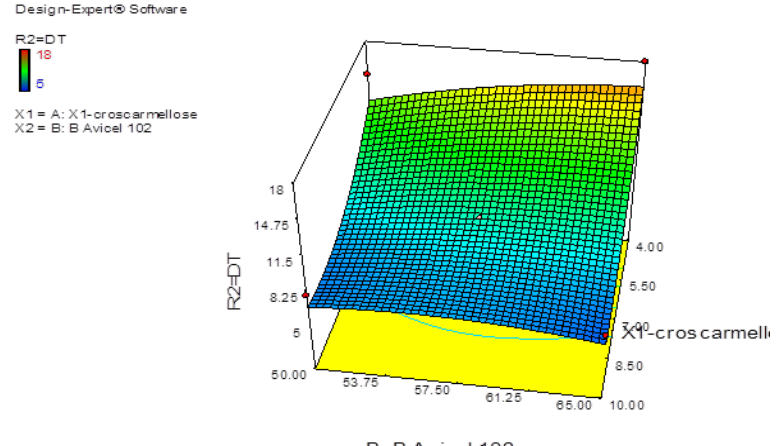

(C) residuals are significant term to look for outliers, i.e., influential values. The DT of trial products was lesser than the marketed comparator brands i.e., 45 and $42 \mathrm{sec}$ respectively for $7.5 \mathrm{mg}$ and $15 \mathrm{mg}$ tablets, but still within the acceptable limits of $15 \mathrm{~min}$. elevated concentrations of ac-di-sol speed up the disintegration process and resulted in the finer dispersion and faster dissolution. In this study, croscarmellose exhibited quadratic/linear response for $7.5 \mathrm{mg}$ and $15 \mathrm{mg}$ formulations respectively. Higher level of superdisintegrant resulted in smaller DT values.
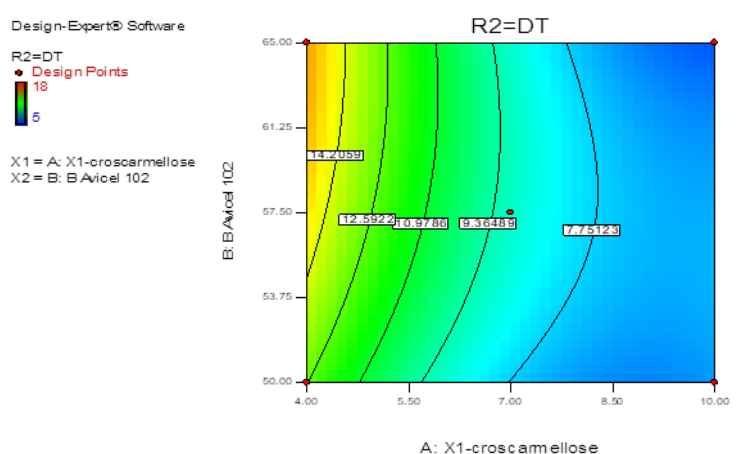

(B)
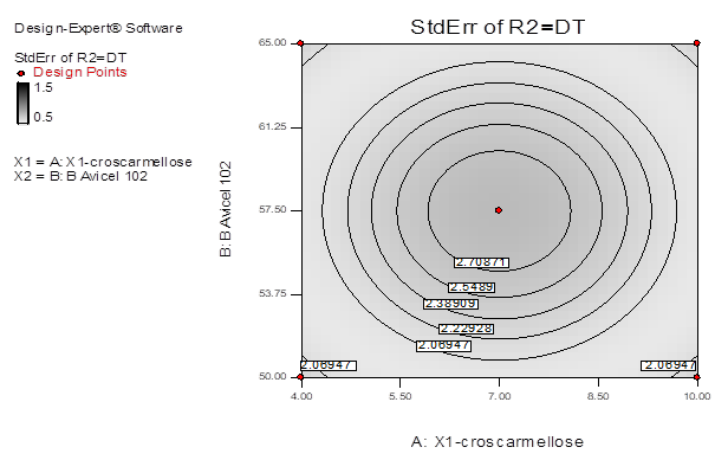

(D)

Figure 2.

Graphical RSM effects of excipients on Disintegration time (DT) of meloxicam $15 \mathrm{mg}$ tablets

Predicted values of disintegration time are shown in Eq. (1) and Eq. (2):

Final Equation in Terms of Coded Factors for DT for $7.5 \mathrm{mg}$ and $15 \mathrm{mg}$ Meloxicam formulations:

$$
\begin{gathered}
\mathrm{Y}_{2}=\mathrm{DT}(15 \mathrm{mg})=9-3.84099 * \mathrm{X}_{1}+0.603553 * \mathrm{X}_{2}-1 * \mathrm{X}_{1} * \mathrm{X}_{2}+2.0625 * \mathrm{X}_{1}^{2}-0.6875 * \mathrm{X}_{2}^{2}, \text { Eq. (1(A)) } \\
\mathrm{Y}_{2}=\mathrm{DT}(7.5 \mathrm{mg})=8.00-1.76 * \mathrm{~A}+0.30 * \mathrm{~B}+0.25 * \mathrm{~A} * \mathrm{~B}+0.062 * \mathrm{~A}^{2}+0.56 * \mathrm{~B}^{2}, \text { Eq. (2(A)) }
\end{gathered}
$$

Interaction Terms:

$$
\begin{aligned}
& \mathrm{Y}_{2}=\mathrm{DT}(15 \mathrm{mg})=-33.73438-1.93311 * \mathrm{X} 1 \text {-croscarmellose }+1.79714 * \text { B Avicel } 102-0.044444 * \mathrm{X} 1- \\
& \text { croscarmellose } * \text { B Avicel } 102+0.22917 * \mathrm{X} 1 \text {-croscarmellose }{ }^{2}-0.012222 * \text { B Avicel } 1022^{2}, \quad \text { Eq. }(1(\mathrm{~B}))
\end{aligned}
$$

$\mathrm{Y}_{2}=\mathrm{DT}(7.5 \mathrm{mg})=+47.66544-1.32241 * \mathrm{X} 1$-croscarmellos $-1.18754 *$ B Avicel $102+0.011111 * \mathrm{X} 1-$ croscarmellose * B Avicel $102+6.94444 \mathrm{E}-003 *$ X1-croscarmellose ${ }^{2}+1.00000 \mathrm{E}-002 *$ B Avicel $102^{2}$, Eq. (2(B))

Porous character of ac-di-sol assists the rapid diffusion of aqueous media into the compacted/core of tablets and in turn resulted in faster tablet dispersal [28]. Abdelbary et al. reported the association of adequate concentration of disintegrants and deaggregation and subsequent dissolution of dispersible tablets [16]. Analysis of variance (ANOVA) was applied to demonstrate the effect of excipients on DT of $\mathrm{M}_{\mathrm{A}} 1$ $M_{A} 9 ; M_{B} 1-M_{B} 9$ and results are summarized in 
FARMACIA, 2019, Vol. 67, 4

(Table V) where ludipress as model term $\mathrm{A}$ has shown the significant effects with $\mathrm{p} \leq 0.005$.

Effect of excipients/adjunct on hardness $(\mathrm{kg})$ of tablet In the present investigation, good correlation between actual and predicted values of hardness was observed. Normal plots of residuals (Figure 3A), contour plots (Figure 3B), three dimensional plots (3D) of RSM (Figure $3 \mathrm{C}$ ) and Standard error plots of disintegration
(Figure 3D) for $15 \mathrm{mg}$ Meloxicam tablets are shown in Figure 3. While related plots for $7.5 \mathrm{mg}$ meloxicam were presented in the Figure 4, which specified the impact of ludipress (X2) on hardness of formulations $\left(\mathrm{M}_{\mathrm{A}} 2-\mathrm{M}_{\mathrm{A}} 9 ; \mathrm{M}_{\mathrm{B}} 2-\mathrm{M}_{\mathrm{B}} 9\right)$ from $3.87 \pm 0.42$ to $5.12 \pm$ $0.67 \mathrm{~kg}$ for $\mathrm{M}_{\mathrm{A}} 2-\mathrm{M}_{\mathrm{A}} 9$ and from $4.18 \pm 0.78$ to $5.03 \pm 0.68 \mathrm{~kg}$ for $\mathrm{M}_{\mathrm{B}} 2-\mathrm{M}_{\mathrm{B}}$ 9. Predicted values were articulated by Eq. (3) and Eq. (4):

Final Equation in Terms of Coded factors for Hardness for $15 \mathrm{mg}$ meloxicam formulation:

$$
\mathrm{Y}_{1}=\text { Hardness }=+4.23-0.032 * \mathrm{~A}+0.54 * \mathrm{~B}-0.028 * \mathrm{~A} * \mathrm{~B}-0.17 * \mathrm{~A}^{2}+0.013 * \mathrm{~B}^{2} \text {, Eq. (3(A)) }
$$

$\mathrm{Y}_{1}=$ Hardness $=-0.51366+0.32684 * \mathrm{X} 1$-croscarmellose $+0.054123 * \mathrm{~B}$ Avicel $102-1.22222 \mathrm{E}-003 * \mathrm{X} 1-$ croscarmellose * B Avicel $102-0.019097 *$ X1-croscarmellose ${ }^{2}+2.33333 \mathrm{E}-004 *$ B Avicel 102 ${ }^{2}$, Eq. (3(B))

Final Equation in Terms of Interaction factors for Hardness for $7.5 \mathrm{mg}$ meloxicam formulation:

$\mathrm{Y}_{1}=$ Hardness $=4.27-0.08873 * \mathrm{~A}+0.522932 * \mathrm{~B}-0.2325 * \mathrm{~A} * \mathrm{~B}-0.22813 * \mathrm{~A}^{2}-0.03813 * \mathrm{~B}^{2}$, Eq. (4(A))

$\mathrm{Y}_{1}=$ Hardness $=-7.17419+0.919452 * \mathrm{X} 1$-croscarmellose $+0.220002 *$ B Avicel $102-0.01033 * \mathrm{X} 1-$ croscarmellose * B Avicel $102-0.02535 *$ X1-croscarmellose ${ }^{\wedge}-0.00068 *$ B Avicel 102^2, Eq. (4(B))
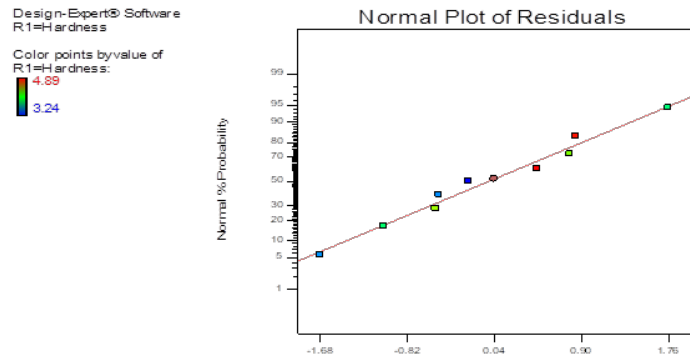

(A)

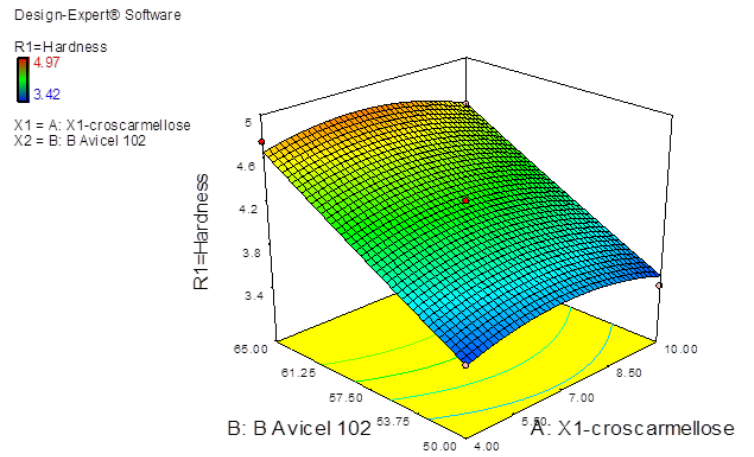

(C)

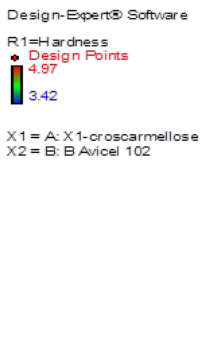

Design-Expertø Software TtdE $\operatorname{err}$ of $R 1=$ Hardness $\prod_{0.5}^{1.5}$ $\mathrm{X} 1=\mathrm{A} \cdot \mathrm{X} 1$-croscarme
$\mathrm{X} 2=\mathrm{B}: \mathrm{B}$ Avicel 102

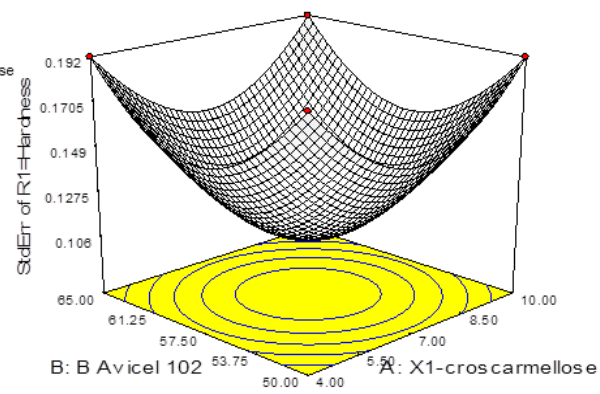

(D)

Figure 3.

Graphical RSM effects of excipients on Hardness of meloxicam $15 \mathrm{mg}$ tablets 


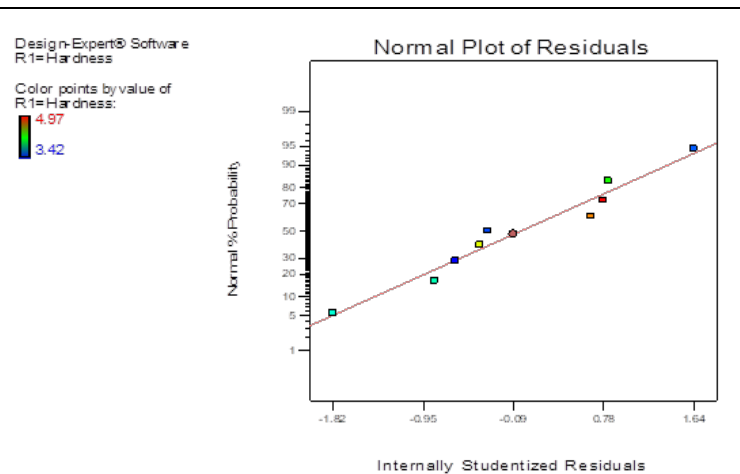

(A)

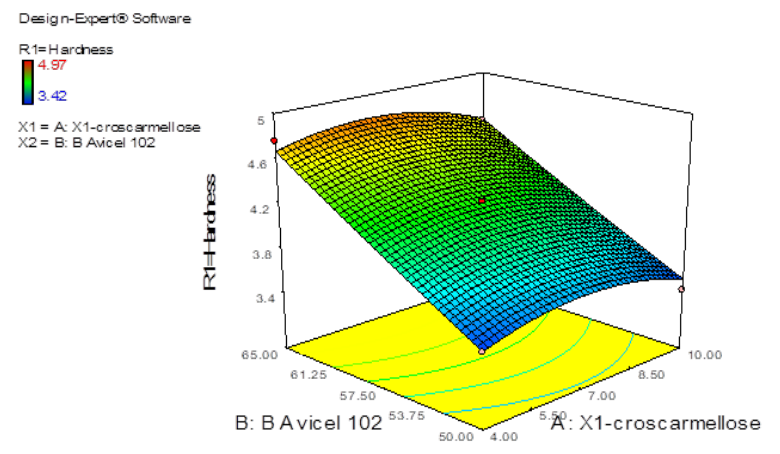

(C)

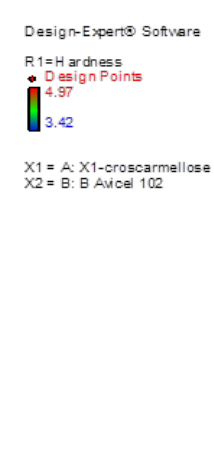

Design-Experte Software

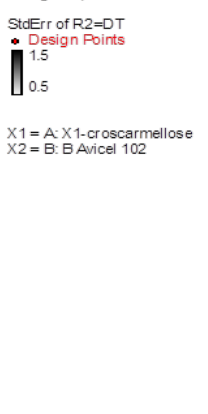

Figure 4.

Graphical RSM effects of excipients on Hardness of meloxicam 7.5 mg tablets
Tablet parameters like friability, hardness and compressional force directly affect the disintegration phenomenon of tablets [29]. Soares et al. determine the excipients effects on crushing strength, friability and disintegration on trial formulations designed by CCRD and results were elucidated by applying RSM [30]. In this study, trial batches were developed and formulated with one centre point, while manifold factorial and axial permutation was incorporated to assess the design applicability. ANOVA (analysis of variance) results were presented in Table V. Kashif et al. developed FDT of flurbiprofen using response surface technique with CCRD [31]. Multiple variables and responses were selected in that study and results have shown the adequacy of design. Zafar et al. in 2012 investigated the concentrations influence of ludipress in FDT formulations of ketoprofen. Study revealed the satisfactory tablet hardness with elevated levels of ludipress and indicated the direct association between force of compression and the in vitro release pattern with decline in DT [32]. In the present

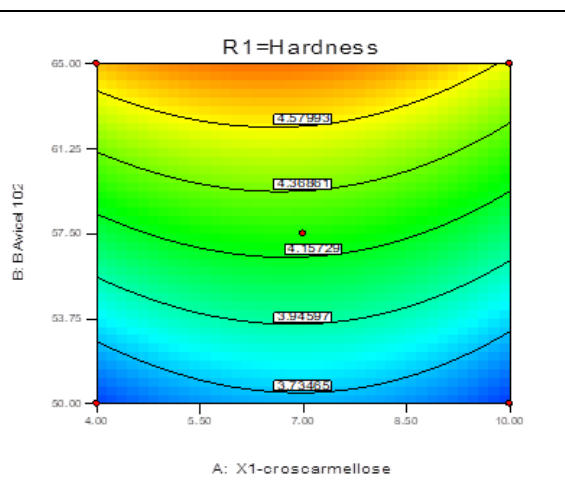

(B)

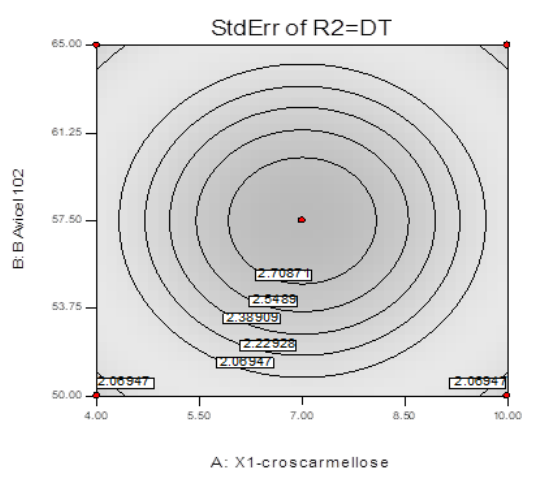

(D) investigation linear fitting of resulted model term and value of coefficient of variance describe the appropriateness of the selected deign.

\section{Stability studies}

Stability assessment of trial formulations of meloxicam $7.5 \mathrm{mg}$ and $15 \mathrm{mg}$ were carried out by following International Committee on Harmonization (ICH) guidelines. Furthermore, the FT IR results have not shown any prospect of interaction and unstable pattern among meloxicam and other excipients utilized in the manufacture of fast dispersible formulations (Figure 5). All these products of 7.5 $\mathrm{mg}$ and $15 \mathrm{mg}$ were observed to be chemically and physically stable throughout the study period and results are summarized Table VI. Kashif et al., in 2016, and Suresh et al., in 2011 also evaluated the stability profile of FDT of flurbiprofen and meloxicam using similar set of criteria and satisfactory results have been reported by these authors [31, 33]. 
Table VI

Stability studies of fast dispersible meloxicam tablets at accelerated condition

\begin{tabular}{|c|c|c|c|c|c|c|c|}
\hline \multicolumn{8}{|c|}{ TRIAL FORMULATIONS MELOXICAM $15 \mathrm{mg}\left(\mathrm{M}_{\mathrm{A}} 2-\mathrm{M}_{\mathrm{A}} 9\right)$} \\
\hline Parameter & Time & $M_{A} 2$ & $M_{A} 4$ & $M_{A} 6$ & $\mathbf{M}_{\mathrm{A}} 7$ & $\mathbf{M}_{\mathrm{A}} \mathbf{8}$ & $\mathbf{M}_{\mathrm{A}} \mathbf{9}$ \\
\hline Assay $(\%)(n=3)$ & \multirow{4}{*}{$\begin{array}{c}0 \\
\text { Month }\end{array}$} & $99.7 \pm 0.48$ & $99.5 \pm 0.33$ & $100.7 \pm 0.52$ & $99.8 \pm 0.67$ & $99.4 \pm 0.48$ & $99.5 \pm 0.39$ \\
\hline Hardness (Kg) & & $3.87 \pm 0.42$ & $4.69 \pm 0.26$ & $5.12 \pm 0.67$ & $4.53 \pm 0.48$ & $4.25 \pm 0.58$ & $4.32 \pm 0.82$ \\
\hline $\begin{array}{c}\text { Disintegration Test (sec) } \\
(n=6)\end{array}$ & & 8 & 7 & 5 & 7 & 5 & 10 \\
\hline Dissolution $(\mathrm{n}=6)$ & & $97.36 \pm 0.67$ & $98.32 \pm 0.43$ & $99.38 \pm 0.86$ & $97.02 \pm 0.28$ & $96.34 \pm 0.36$ & $97.39 \pm 0.25$ \\
\hline Assay $(\%)(n=3)$ & \multirow{4}{*}{$\begin{array}{c}1 \\
\text { Month }\end{array}$} & $99.4 \pm 1.25$ & $99.3 \pm 1.48$ & $100.3 \pm 1.32$ & $99.5 \pm 1.68$ & $99.1 \pm 1.39$ & $99.0 \pm 1.59$ \\
\hline Hardness $(\mathrm{Kg})$ & & $3.84 \pm 0.36$ & $4.52 \pm 0.65$ & $5.12 \pm 1.53$ & $4.47 \pm 0.63$ & $4.13 \pm 0.74$ & $4.21 \pm 0.52$ \\
\hline $\begin{array}{l}\text { Disintegration Test }(\mathrm{sec}) \\
(\mathrm{n}=6)\end{array}$ & & 9 & 8 & 7 & 9 & 9 & 12 \\
\hline Dissolution $(n=6)$ & & $97.05 \pm 0.98$ & $98.21 \pm 0.86$ & $99.16 \pm 0.59$ & $98.18 \pm 0.49$ & $95.94 \pm 0.83$ & $97.22 \pm 0.79$ \\
\hline Assay $(\%)(n=3)$ & \multirow{4}{*}{$\begin{array}{c}3 \\
\text { Month }\end{array}$} & $101.21 \pm 1.11$ & $101.28 \pm 1.74$ & $101.25 \pm 1.62$ & $101.15 \pm 1.61$ & $100.13 \pm 1.27$ & $99.17 \pm 1.55$ \\
\hline Hardness $(\mathrm{Kg})$ & & $3.90 \pm 0.54$ & $4.67 \pm 0.79$ & $5.17 \pm 1.07$ & $4.43 \pm 0.59$ & $4.08 \pm 0.89$ & $4.27 \pm 0.74$ \\
\hline $\begin{array}{l}\text { Disintegration Test (sec) } \\
(\mathrm{n}=6)\end{array}$ & & 11 & 10 & 9 & 10 & 8 & 15 \\
\hline Dissolution $(n=6)$ & & $96.89 \pm 0.48$ & $98.01 \pm 0.69$ & $99.48 \pm 0.58$ & $97.79 \pm 0.88$ & $96.05 \pm 0.96$ & $97.17 \pm 0.85$ \\
\hline
\end{tabular}

\begin{tabular}{|c|c|c|c|c|c|c|c|}
\hline Parameter & Time & $M_{B} 2$ & $M_{B} 4$ & $M_{B} 6$ & $\mathbf{M}_{\mathrm{B}} 7$ & $\mathbf{M}_{\mathrm{B}} 8$ & $\mathbf{M}_{\mathrm{B}} 9$ \\
\hline Assay $(\%)(n=3)$ & \multirow{4}{*}{$\begin{array}{c}0 \\
\text { Month }\end{array}$} & $100.1 \pm 0.75$ & $99.45 \pm 0.59$ & $100 \pm 0.84$ & $99.1 \pm 0.93$ & $98.7 \pm 0.83$ & $99.2 \pm 0.15$ \\
\hline Hardness (Kg) & & $5.03 \pm 0.68$ & $4.37 \pm 0.56$ & $4.18 \pm 0.78$ & $4.92 \pm 0.69$ & $4.79 \pm 0.46$ & $4.53 \pm 0.59$ \\
\hline $\begin{array}{l}\text { Disintegration Test (sec) } \\
(\mathrm{n}=6)\end{array}$ & & 9 & 8 & 7 & 8 & 4 & 5 \\
\hline Dissolution $(n=6)$ & & $99.83 \pm 0.89$ & $98.39 \pm 0.32$ & $99.86 \pm 0.91$ & $97.54 \pm 0.57$ & $98.45 \pm 0.54$ & $97.56 \pm 0.67$ \\
\hline Assay $(\%)(n=3)$ & \multirow{4}{*}{$\begin{array}{c}1 \\
\text { Month }\end{array}$} & $99.98 \pm 0.51$ & $99.37 \pm 0.58$ & $99.99 \pm 0.79$ & $98.8 \pm 0.93$ & $98.5 \pm 0.76$ & $98.9 \pm 0.87$ \\
\hline Hardness (Kg) & & $5.05 \pm 0.74$ & $4.39 \pm 0.58$ & $4.19+0.67$ & $4.89 \pm 0.86$ & $4.75 \pm 0.58$ & $4.63 \pm 0.54$ \\
\hline $\begin{array}{l}\text { Disintegration Test (sec) } \\
(n=6)\end{array}$ & & 10 & 13 & 9 & 11 & 9 & 10 \\
\hline Dissolution $(n=6)$ & & $99.24 \pm 0.94$ & $99.62 \pm 0.78$ & $99.68 \pm 0.59$ & $98.05 \pm 0.84$ & $98.76 \pm 0.97$ & $97.08 \pm 0.92$ \\
\hline Assay $(\%)(n=3)$ & \multirow{4}{*}{$\begin{array}{c}3 \\
\text { Month }\end{array}$} & $99.86 \pm 0.85$ & $99.28 \pm 0.96$ & $99.87 \pm 0.64$ & $98.8 \pm 0.85$ & $97.7 \pm 0.88$ & $98.6 \pm 0.65$ \\
\hline Hardness (Kg) & & $5.10 \pm 0.68$ & $4.38 \pm 1.76$ & $4.20 \pm 0.69$ & $4.95 \pm 0.63$ & $4.81 \pm 1.05$ & $4.75 \pm 1.17$ \\
\hline $\begin{array}{l}\text { Disintegration Test (sec) } \\
(\mathrm{n}=6)\end{array}$ & & 13 & 17 & 12 & 15 & 14 & 13 \\
\hline Dissolution $(n=6)$ & & $99.25 \pm 0.49$ & $98.79 \pm 0.86$ & $99.97 \pm 0.64$ & $97.15 \pm 0.82$ & $97.68 \pm 0.69$ & $97.37 \pm 0.99$ \\
\hline
\end{tabular}

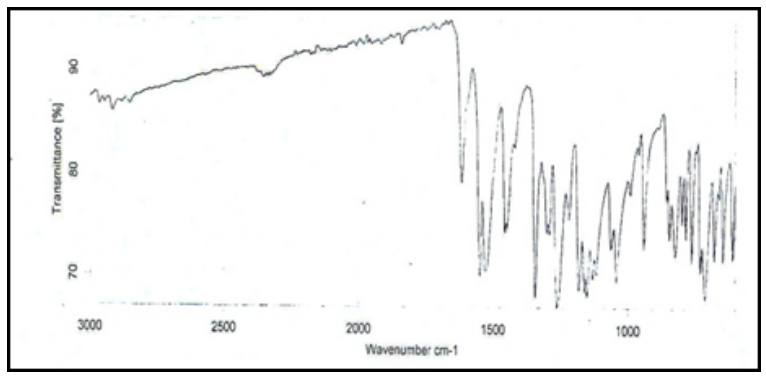

(A)

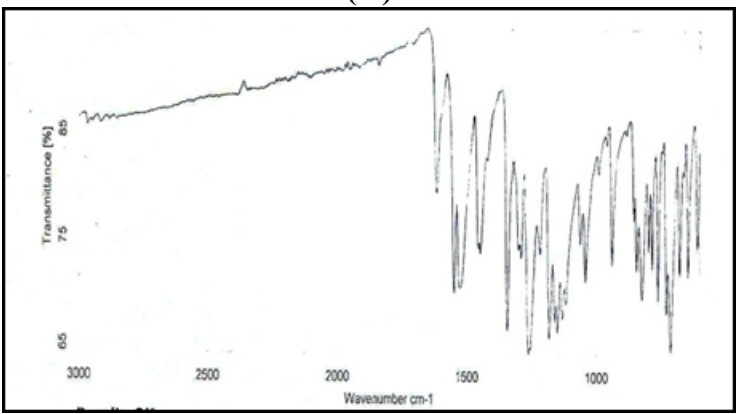

(C)

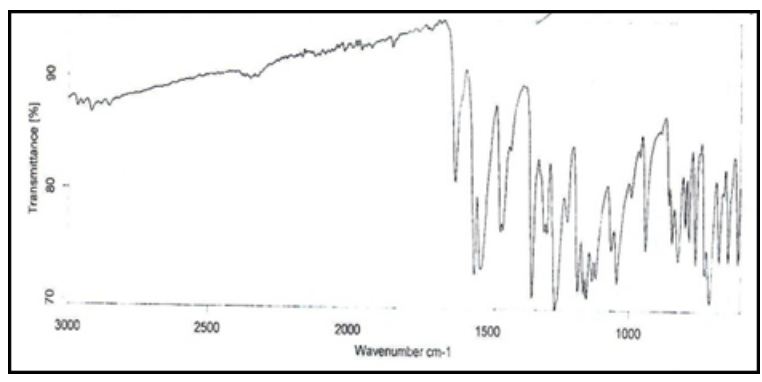

(B)

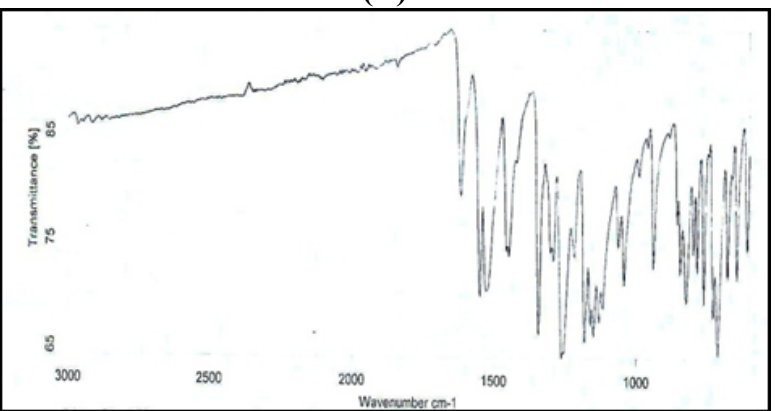

(D)

Figure 5.

FT-IR spectra of meloxicam and excipients ((A) Pure drug Meloxicam, (B) Physical mixture of API and Disintegrant, (C) Optimized formulation $\mathrm{M}_{\mathrm{A}} 6$, and (D) Optimized formulation $\mathrm{M}_{\mathrm{B}} 6$ ) 


\section{Conclusions}

Response surface methodology is the widely used approach in the optimization of drugs products. It consists of different statistical and mathematical experiments which help in optimization, development and improvement of process. CCRD is a second order design and has an advantage of fewer numbers of experiments. This study satisfactorily concluded the preliminary work stage of FDT of meloxicam $7.5 \mathrm{mg}$ and $15 \mathrm{mg}$ formulations, where independent variables and their values are determined, an experimental design with optimum equation are determined and verified. After that the plot of response surfaces of independent variables with selected dependent factors are constructed to reach a target value. Fast dispersible formulations of meloxicam tablets have shown adequate test results.

\section{References}

1. Singh J, Singh R, Optimization and Formulation of Orodispersible Tablets of Meloxicam. Trop $J$ Pharmaceut Res., 2009; 8 (2): 153-159.

2. Madgulkar A, Bhalekar M, Swami M, In Vitro and In Vivo Studies on Chitosan Beads of Losartan Duolite AP143 Complex, Optimized by Using Statistical Experimental Design. AAPS PharmSciTech., 2009; 10(3): 743-751.

3. Khan A, Khan J, Zafar M, Irfan M, Rabbani I, Formulation Development and Optimization of Intermediate Release Metoclopramide $\mathrm{HCl}$ Tablets by Central Composite Rotatable Design for IVIVC Studies. Int J Innov Sci Modern Engin., 2015; 3(2): 21-30.

4. Shirsand SB, Suresh S, Kusumdevi V, Swamy PV, Formulation Design and Optimization of Fast Dissolving Clonazepam Tablets by Sublimation Method. Ind $J$ Pharmaceut Sci., 2011; 73(5): 491-496.

5. Ali H, Shoaib MH, Zafar F, Yousuf RI, Alam ZM, Khursheed R, Siddiqui S, Development and Optimization of Diclofenac Potassium Tablets Using Central Composite Design and Dissolution Profile Comparison. Lat Am J Pharm., 2013; 32(7): 1058-1068.

6. Bushra R, Shoaib MH, Ali H, Zafar F, Naeem MI, Aslam N, Formulation Design and Optimization of Aceclofenac Tablets (100 mg) Using Central Composite Design with Response Surface Methodology. Lat Am J Pharm., 2014; 33(6): 1009-1018.

7. Bolhuis GK, Armstrong NA, Excipients for Direct Compaction - an Update. Pharmaceut Develop Tech., 2006; 11(1): 111-124.

8. Reddy L, Ghosh B, Fast dissolving drug delivery systems: A review of the literature. IJPS, 2002; 64(4): 331-336.

9. Obaidat AA, Obaidat RM, Development and evaluation of fast-dissolving tablets of meloxicamb-cyclodextrin complex prepared by direct compression. Acta Pharm., 2011; 61: 83-91.

10. British Pharmacopoeia. London: Stationary Office London, 2013.
11. United States Pharmacopoeia. $36^{\text {th }}$ ed.(NF $\left.31^{\text {st }}\right)$. The United Sates Pharmacopoeial convention. 12601 Twinbrook Parkway, Rockville: MD 20852, 2013.

12. European Pharmacopoeia, $3^{\text {rd }}$ ed. European Department for the Quality of Medicines, Strasbourg. Supplement, 2001.

13. Elbary AA, Ali AA, Aboud HM, Enhanced dissolution of Meloxicam from orodispersible tablets prepared by different methods. Bul Fac Pharm, Cairo Univ., 2012; 50(2): 89-97.

14. Asia N, Huma A, Farya Z, Shabana NS, Huma S, Shehla S, Zeb-un-N, Ghazala RN, Development of Spectrophotometric Method for Dissolution and In Vitro Kinetic Study of Glimepiride Tablets. Lat Am J Pharm., 2014; 33(9): 1418-1424.

15. ICH QIA (R2). Stability testing guidelines: stability testing of new drug substances and products. ICH Steering Committee, 2003.

16. Abdelbary A, Elshafeey AH, Zidan G, Comparative effects of different cellulosic-based directly compressed orodispersable tablets on oral bioavailability of Famotidine. Carbohydrate Polymer, 2009; 77: 799806.

17. Faqih A, Chaudhuri B, Alexander AW, Davies C, Muzzio FJ, Silvina TM, An experimental/computational approach for examining unconfined cohesive powder flow. Int J Pharm., 2006; 324: 116-127.

18. Rakhi B Shah, Mobin A Tawakkul, Mansoor A Khan, Comparative Evaluation of Flow for Pharmaceutical Powders and Granules. AAPS PharmSciTech., 2008; 9(1): 250-257.

19. Ali H, Harris MS, Zafar F, Bushra R, Riffat Y, Shehla S, Zafar MA, Intermediate release formulations of diclofenac potassium tablets for IVIVC. Pak $J$ Pharm Sci., 2016; 29(4): 1287-1298.

20. Martinello T, Kaneko TM, Velasco MV, Taqueda ME, Consiglieri VO, Optimization of poorly compactable drug tablets manufactured by direct compression using the mixture experimental design. Int J Pharm., 2006; 322(1-2): 87-95.

21. Liu LX, Marziano I, Bentham AC, Litster JD, White ET, Howes T, Effect of particle properties on the flowability of Ibuprofen powders. Int J Pharmaceut., 2008; 362: 109-117.

22. Ali H, Harris MS, Farya Z, Rabia IY, Zafar MA, Raheela K, Shehla S, Development and Optimization of Diclofenac Potassium Tablets Using Central Composite Design and Dissolution Profile Comparison. Lat Am J Pharm., 2013; 32(7): 1058-1068.

23. Chandrasekhar R, Hassan Z, AlHusban F, Smith A, Mohammed A, The role of formulation excipients in the development of lyophilized fast-disintegrating tablets. Eu J Pharmaceut Biopharmaceut., 2009; 72: 119-129.

24. Anna B, Ali MI, Formulation Development and Characterization Of Nisoldipine Fast Dissolving Tablet. Int J Pharm Pharmaceut Sci., 2014; 6(2): 532-535.

25. Arulsudar N, Subramanian N, Murthy R, Comparison of artificial neural network and multiple line regression in the optimization of formulation parameters of leuprolide acetate loaded liposomes. J Pharm Pharmaceut Sci., 2005; 8: 243-258. 
26. Ragonese R, Macka M, Hughes J, Petocz P, The use of the Box-Behnken experimental design in the optimisation and robustness testing of a capillary electrophoresis method for the analysis of ethambutol hydrochloride in a pharmaceutical formulation. $J$ Pharmaceut Biomed Analys., 2002: 27(6): 995-1007.

27. Bezerra MA, Santelli RE, Oliveira EP, Villar LS, Escaleira LA, Response surface methodology (RSM) as a tool for optimization in analytical chemistry. Talanta, 2008; 76(5): 965-977.

28. Di Martino P, Martelli S, Wehrle P, Evaluation of different fast melting disintegrants by means of a central composite design. Drug Dev Ind Pharm., 2005; 31(1): 109-121.

29. Mishra DN, Bindal M, Singh SK, Kumar SG, Spray dried excipient base: A novel technique for the formulation of orally disintegrating tablets. Chem Pharmaceut Bul., 2006; 54: 99-102.
30. Soares LA, Ortega GG, Petrovick PR, Schmidt PC, Optimization of tablets containing a high dose of spray-dried plant extract: a technical note. AAPS PharmSciTech., 2005; 6(3): E367-371.

31. Kashif M, Farya Z, Huma A, Shabana NS, Rabia B, Safila N, Muhammad SQ, Sohail K, Shehla S, Development and Optimization of Fast Dispersible Flurbiprofen $100 \mathrm{mg}$ Tablets by Central Composite Design. Lat Am J Pharm., 2016; 35(4): 685-694.

32. Zafar F, Shoaib MH, Yousuf RI, Development and Evaluation of Fast Dispersible Ketoprofen 100mg tablets. As J Pharmaceut Res., 2012; 2(1): 1-9.

33. Suresh VK, Ranjit KP, Nikunj P, Someshwara RB, Ramesh B, Ashok KP, Formulation and evaluation of fast disintigrating meloxicam tablets and its comparison with marketed product. Int J Pharm Pharm Sci., 2011; 3(1): 91-93. 